\title{
14. CALCAREOUS NANNOPLANKTON BIOGEOGRAPHY AND ITS PALEOCLIMATIC IMPLICATIONS: CENOZOIC OF THE FALKLAND PLATEAU (DSDP LEG 36) AND MIOCENE OF THE ATLANTIC OCEAN
}

\author{
Bilal U. Haq and G.P. Lohmann, Woods Hole Oceanographic Institution, Woods Hole, Massachusetts \\ and \\ Sherwood W. Wise, Jr., Florida State University, Tallahassee, Florida
}

\section{INTRODUCTION}

Latitudinal differentiation in calcareous nannoplankton assemblages is known to have existed throughout the Cenozoic and probably through most of the Mesozoic. In the early Cenozoic such latitudinally differentiated assemblages have shown distinct migrations across latitudes with time. In a study of the nannoplankton biogeography of the Atlantic basin, Haq and Lohmann (1976) have documented five such major migrationary events in the early Cenozoic: (1) invasion of low latitudes by Paleocene high latitude assemblages between 59 and 57 m.y.B.P., (2) invasion of high latitudes by late Paleocene-early Eocene low to mid latitude assemblages between 54 and 52 m.y.B.P., (3) invasion of middle latitudes by Eocene high latitude assemblages between 48 and 43 m.y.B.P., (4) invasion of low latitudes by late Eocene-early Oligocene high latitude assemblages between 37 and 36 m.y.B.P., and (5) invasion of middle latitudes by Oligocene high latitude assemblages between 32 and 27 m.y.B.P. These events were interpreted as responses of the nannoflora to major fluctuations in the climate of the early Cenozoic (see Haq and Lohmann, 1976, fig. 18).

The above study was based on DSDP material from the North and Central Atlantic only. Due to lack of drill sites in the southern high latitudes at the time of the study, no biogeographic data from South Atlantic higher than $30^{\circ} \mathrm{S}$ (Leg 3 sites) could be considered. During DSDP Leg 36, two open-ocean sites were drilled on the eastern end of the Falkland Plateau (Figure 1), both of which are above $50^{\circ} \mathrm{S}$ latitude (Site 327: $50^{\circ} 42.38^{\prime} \mathrm{S}$ and Site 329: $50^{\circ} 39.31^{\prime} \mathrm{S}$ ) in water depths shallow enough for the preservation of early Cenozoic and Miocene calcareous plankton. Due to its position, this area is critical to the delineation of biogeographic patterns and the paleooceanography of the Southern Ocean. The objective of this paper is to extend Atlantic nannoplankton biogeography into the southern high latitudes and to compare the results with the distributional patterns in the northern high latitudes and the low to middle latitudes of the Atlantic.

\section{TIME INTERVALS CONSIDERED}

All the available Cenozoic material from DSDP Hole $327 \mathrm{~A}$ and Site 329 was examined for the preservation of calcareous nannoplankton. All samples from Hole $327 \mathrm{~A}$, Core 9 through Core 2, showed poor preservation and excessive fragmentation of coccoliths, and a meaningful census of coccolith taxa could not be obtained. Samples from Site 329 showed varying degrees of coccolith dissolution, with moderately well preserved coccoliths at some levels in Cores 33 through 3 . Upper Paleocene, lower Oligocene, and Miocene horizons in particular contained coccoliths well enough preserved that the relative abundances of various groups could be determined. The horizon containing early Eocene (Tribrachiatus orthostylus Zone-see Wise and Wind, this volume) showed poor preservation and fragmentation of more susceptible taxa and is not considered here.

On the basis of preservation, 12 time intervals (two in the late Paleocene, two in the early Oligocene, and eight in the Miocene) were chosen for coccolith census and intrabasinal comparison:

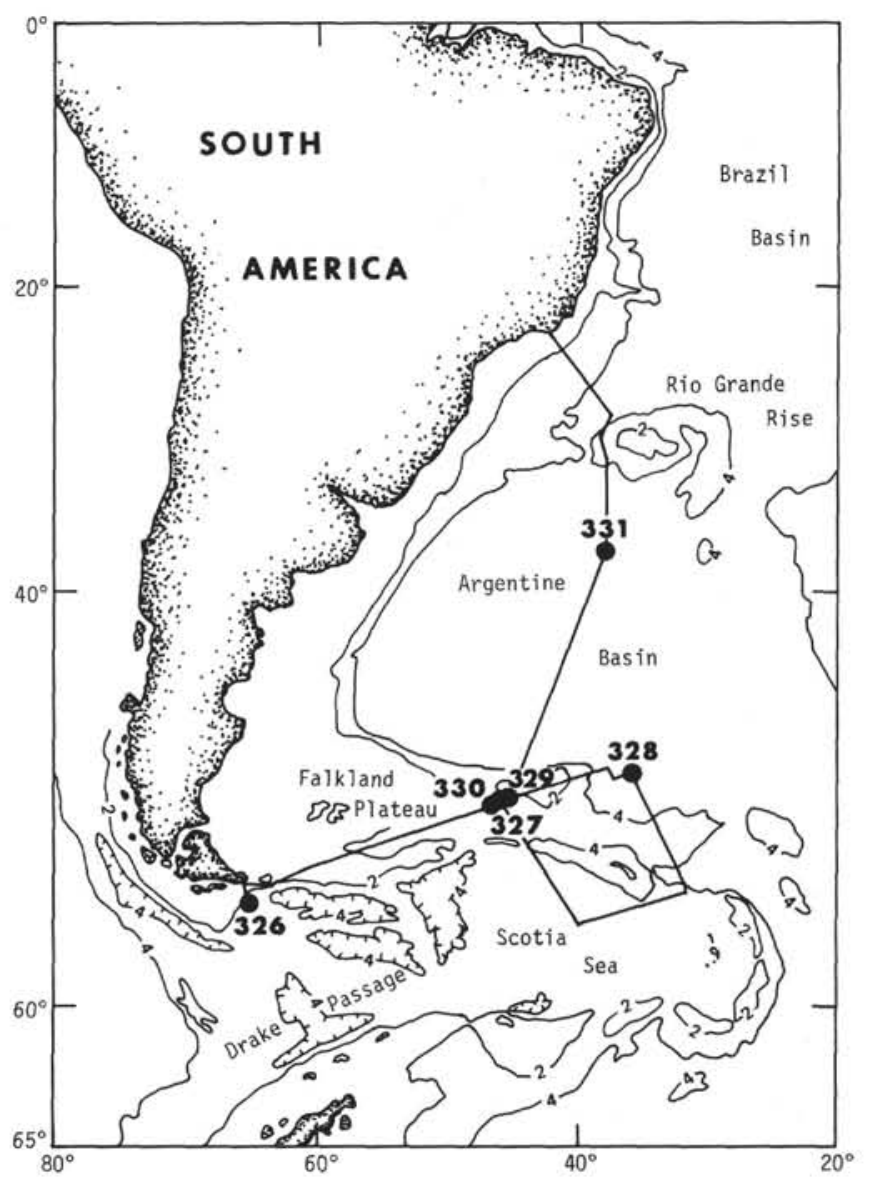

Figure 1. Location of DSDP Leg 36 Sites. 
Time Interval 1: Lower Part of Discoaster multiradiatus (NP9) Zone (56 to 55 m.y.B.P.)

This horizon is characterized by late Paleocene coccolith taxa, but only a single discoaster species, $D$. multiradiatus. Sample 329-33-3, 118-120 cm is considered a representative sample for this interval.

Time Interval 2: Upper Part of Discoaster multiradiatus (NP9) Zone (55.5 to 53 m.y.B.P.)

At Site 329, Core 32, species of discoasters, such as D. falcatus, D. lenticularis, and (in the upper section of the core) $D$. barbadiensis, were recorded in addition to the flora recorded in Core 33. These additional discoaster taxa are more typical of the upper part of the NP9 Zone. Sample 329-32-4, 5-7 cm is chosen to represent this time interval.

\section{Time Interval 3: Ericsonia subdisticha/}

Helicopontosphaera reticulata (NP 21/22) Zones (37.5 to 35 m.y.B.P.)

This horizon contains a characteristic late Eoceneearly Oligocene nannoflora; however, the zone diagnostic taxa, such as helicopontosphaerids and sphenoliths are absent. Due to the presence of Ericsonia subdisticha and rare occurrence of Reticulofenestra umbilica and Cyclococcolithus formosus, this time slice can be assigned to a mixed NP 21/22 Zone. Sample 329-30$3,78-80 \mathrm{~cm}$ is considered a representative sample for this interval.

Time Interval 4: Upper Part of Helicopontosphaera reticulata to Sphenolithus predistentus (NP 22/23) Zones (36 to 32 m.y.B.P.)

This level covers a rather large period of 4 m.y. No Cyclococcolithus formosus was seen, but very rare specimens of Reticulofenestra umbilica are still present. On the basis of foraminifera (see Tjalsma, this volume), this level has been assigned to the later part of the early Oligocene. Due to these considerations we assign this horizon to the NP 22/23 nanno zones and an age of 36 to 32 m.y.B.P. Sample $329-28-1,15-17 \mathrm{~cm}$ is considered representative for this interval.

\section{Time Interval 5: Early Miocene (22.5 to 21 m.y.B.P)}

In Core 27 rare to few specimens of Reticulofenestra bisecta and Dictyococcites abisectus were observed. These forms could not be reworked since we found no other reworked taxa. Other coccolith taxa observed, though not zone diagnostic, are common in the earliest Miocene. On the basis of these observations, we place this time interval between 22.5 to 21 m.y.B.P. Sample $329-27-1,120-124 \mathrm{~cm}$ is considered representative.

Time Intervals 6-12: Middle to Late Miocene (16-14, 12 10, 11-9, 10.5-8.5, 10-8, 9-7, and 8-6 m.y.B.P.)

Eight time intervals are chosen from Cores 23 to 3 representing sediments from middle to late Miocene on the basis of the availability of well-preserved nannoflora. In the absence of age-diagnostic species, ages assigned to these time intervals are based on sedimentation rates of these cores. For representative samples see Table 1.

\section{CENSUS DATA AND PALEOBIOGEOGRAPHY}

In smear slides made from raw samples representing each time interval 100 to 300 specimens (depending on the floral diversity) were counted. Table 2 lists the census data expressed as percent.

\section{Late Paleocene Assemblages}

The late Paleocene assemblages of the Falkland Plateau are characterized by the same taxa that dominate the mid to low latitudes of this time. However, there are distinct differences in the relative abundance of these taxa, and additional taxa also occur at this site (Figure 2).

During the first time slice (56-55 m.y.B.P.), a Toweius craticulus-Coccolithus pelagicus assemblage dominates, much like the mid to low latitudes of the same time (see Haq and Lohmann, 1976, fig. 6B). This is a relatively low-latitude assemblage (Haq and Lohmann, 1976, table 9) which migrates into the higher latitudes during the late Paleocene-early Eocene interval. Like the mid to low latitudes, minor amounts of Ericsonia subpertusa, fasciculiths, and discoasters are also present.

This nannoflora, however, differs in some significant respects from the northern high latitude floras of the same time. In the northern high latitudes (e.g., DSDP Hole 117A) Prinsius martinii is the dominant assemblage from 63 to 54 m.y.B.P., and the Toweius craticulus-Coccolithus pelagicus assemblage is less prominent, becoming dominant only in the latest Paleocene-early Eocene. On the Falkland Plateau, however, the latter assemblage is more prominent than the former which comprises only about $8.3 \%$ of the total flora (as compared to $55.3 \%$ at northern Site 117).

Another striking difference between the northern and southern high latitudes is the prominence of chiasmoliths on the Falkland Plateau (up to $19.6 \%$ of the total flora). Chiasmoliths are found in much smaller numbers (up to $4.3 \%$ ) at Site 117. Another difference is the presence of Hornibrookina australis at Site 329, which is absent in the northern high latitudes of the Atlantic and, in fact, has been recorded only once from the northern hemisphere (Crimea, Perch-Nielsen, personal communication). Genus Hornibrookina has been reported from Danian to early Eocene of such southern high latitude areas as New Zealand, Tasman Sea (Edwards and Perch-Nielsen, 1975), Bellingshausen Abyssal Plain (Haq, 1976), and may prove to be a provincial taxon peculiar to the southern latitudes.

In the latest Paleocene (55.5-53.5 m.y.B.P.) the dominant assemblages remain the same as earlier, however, chiasmoliths are reduced in prominence (from $19.6 \%$ to $9.6 \%)$. Hornibrookina australis, on the other hand, increases in abundance (from $1 \%$ in time interval 1 , to $6.3 \%$ in time interval 2 ).

These comparisons indicate a "mixed" nature of the assemblages of Falkland Plateau during the late Paleocene. The dominance by warm low latitude assemblages, the prominence of chiasmoliths (coolwater), and the continued presence of Prinsius martinii (cool water) in time-interval 2 (as compared to northern high latitudes where this taxon is absent during this time), all suggest dual influences of cool and warm water nannofloras. 
TABLE 1

Census Data for the Miocene Time Intervals, Site 329

\begin{tabular}{|c|c|c|c|c|c|c|c|c|}
\hline Species & 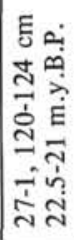 & 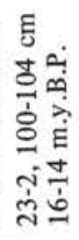 & 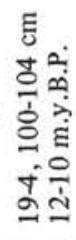 & 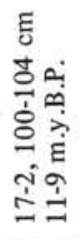 & 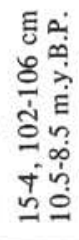 & 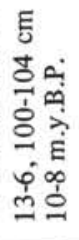 & 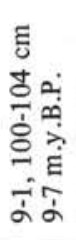 & 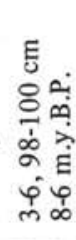 \\
\hline Coccolithus pelagicus & 23 & 3 & 5 & 8 & 1 & 29 & 14 & 61 \\
\hline Dictyococcites hesslandii & 39 & 0 & 0 & 0 & 0 & 0 & 0 & 0 \\
\hline Cyclococcolithus neogammation & 8 & 2 & 0 & 0 & 0 & 0 & 0 & 0 \\
\hline C. aff. neogammation & 1 & 0 & 0 & 0 & 0 & 0 & 0 & 0 \\
\hline Dictyococcites abisectus & 6 & 0 & 0 & 0 & 0 & 0 & 0 & 0 \\
\hline Reticulofenestra bisecta & 6 & 0 & 0 & 0 & 0 & 0 & 0 & 0 \\
\hline Coccolithus miopelagicus & 6 & 0 & 0 & 5 & 2 & 21 & 19 & 7 \\
\hline Dictyococcites antarcticus & 0 & 85 & 75 & 42 & 93 & 20 & 40 & 13 \\
\hline Reticulofenestra aff. pseudoum & 0 & 2 & 11 & 32 & 1 & 19 & 19 & 7 \\
\hline Cyclococcolithus macintyrei & 0 & 0 & 0 & 1 & 0 & 1 & 0 & 0 \\
\hline Etc. (unidentifiable forms) & 12 & 8 & 9 & 12 & 3 & 11 & 7 & 12 \\
\hline
\end{tabular}

TABLE 2

Census Data for the Four Selected Time Intervals in the Early Cenozoic, Site 329 (Actual Numbers are Converted into Percentage of Total Flora)

\begin{tabular}{|c|c|c|c|c|c|}
\hline \multirow[b]{2}{*}{ Species } & \multicolumn{2}{|c|}{ Late Paleocene } & \multirow[b]{2}{*}{ Species } & \multicolumn{2}{|c|}{ Oligocene } \\
\hline & 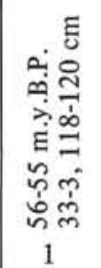 & 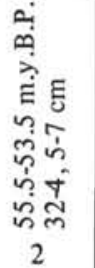 & & 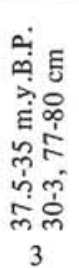 & 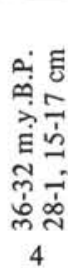 \\
\hline C. pelagicus & 14.3 & 5.3 & D. hesslandii & 10 & 4.3 \\
\hline T. craticulus & 24.3 & 32 & C. neogammation & 5.6 & 7 \\
\hline P. martinii & 8.3 & 14 & Reticulofenestra spp. & 17 & 18 \\
\hline E. subpertusa & 6 & 7.6 & Sphenolithus spp. & 0 & 0.6 \\
\hline Thoracosphaera spp. & 0.6 & 1.3 & C. pelagicus & 15.6 & 20.3 \\
\hline Fasiculithus spp. & 6.3 & 5.6 & R. bisecta & 0.6 & 0.6 \\
\hline P. bisulcus & 0.3 & 0 & Discoaster spp. & 0.6 & 0 \\
\hline Chiasmolithus spp. & 19.6 & 9.6 & C. eopelagicus & 10.3 & 4.3 \\
\hline Discoaster spp. & 4.6 & 2.6 & Z. bijugatus & 1.3 & 0 \\
\hline Zygodiscus spp. & 1 & 0.6 & C. formosus & 2 & 0 \\
\hline T. eminens & 1.6 & 2 & E. subdisticha & 11.3 & 1.3 \\
\hline Hornibrookina sp. & 1 & 6.3 & Chiasmolithus sp. & 13.6 & 27 \\
\hline Sphenolithus spp. & 1.3 & 1 & R. abisecta & 0.6 & 2.3 \\
\hline Z. bijugatus & 3.3 & 5.3 & R. umbilica & 0.6 & 0.3 \\
\hline etc. & 7 & 6.3 & etc. & 10.3 & 13.6 \\
\hline
\end{tabular}

\section{Oligocene Assemblages}

In the third selected time interval (37.5-35 m.y.B.P.) the nannoflora at Site 329 is dominated by small to medium sized reticulofenestrid species, Coccolithus pelagicus, and by an unusually large number of chiasmoliths (represented by a single taxon, $C$. altus). Other prominent, though relatively less abundant, taxa are: Ericsonia subdisticha, Dictyococcites hesslandii, and Cyclococcolithus neogammation. In comparison, the middle to low latitudes of the same time period were dominated by $C$. neogammation, $D$. hesslandii, and lesser amounts of reticulofenestrids, and Coccolithus eopelagicus (with minor amounts of sphenoliths and discoasters and Reticulofenestra bisecta). The northern high latitude open-ocean sites (e.g., Site 112), on the other hand, were also dominated by reticulofenestrids, but with equally substantial amounts of Cyclococcolithus neogammation and Dictyococcites hesslandii and lesser amounts of Coccolithus pelagicus (see Haq and Lohmann, 1976, appendix table 2C). 


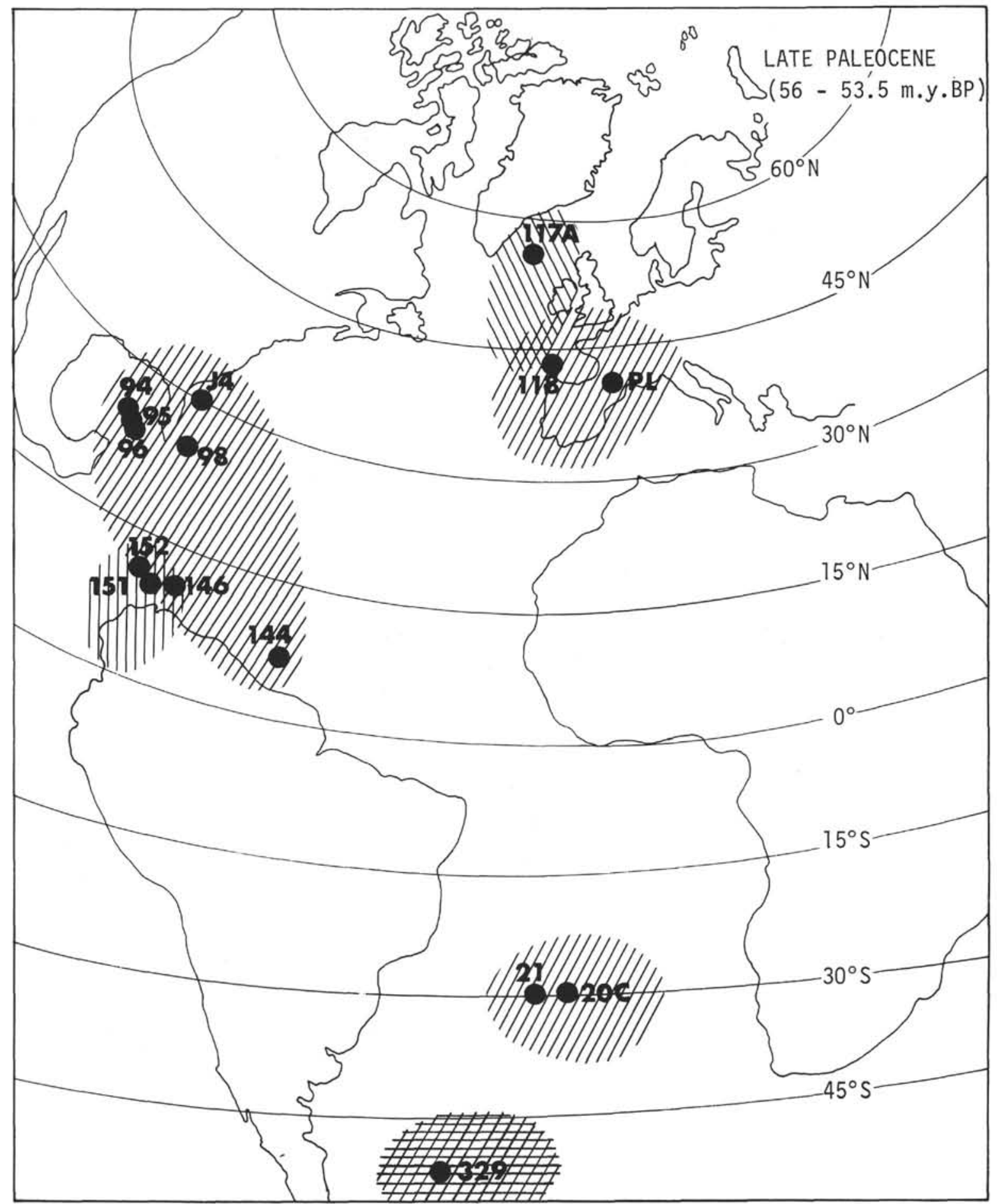

Prinsius martinii Assemblage
Toweius craticulus

\& Coccolithus

pelagicus Assemblage
Chiasmolith

Assemblage

Discoaster

\& Cyclococcolithus formosus

Assemblage

Figure 2. Late Paleocene calcareous nannoplankton biogeography plotted on the reconstruction of paleoAtlantic Ocean 56 to 53 m.y.B.P. (see Haq and Lohmann, 1976). The most distinctive assemblages for each latitudinal area are shown around the site in which they are recorded. 
The most striking difference between northern and southern high latitudes of this time, much like the late Paleocene, is the occurrence of a large number of chiasmoliths which are either very rare or absent in most other Oligocene sites of the Atlantic (see Figure 3).

In time interval 4 (36-32 m.y.B.P.), the biogeographic relationships remain essentially similar to time interval 3 , except that the chiasmoliths become more dominant than reticulofenestrids and Coccolithus pelagicus (up to $27 \%$ of the total flora). There is a noticeable decrease in the abundance of Dictyococcites hesslandii and Coccolithus eopelagicus, and Ericsonia subdisticha is reduced drastically. In the northern high latitudes at this time Dictyococcites hesslandii, Cyclococcolithus neogammation, and reticulofenestrids were all equally prominent and chiasmoliths were absent. Thus, there is a greater biogeographic distinction between the northern and southern high latitudes of this time as compared to the last time interval.

\section{Miocene Assemblages and Paleobiogeography of the Atlantic Ocean}

In this section together with Leg 36 results, we include the preliminary results of the study on Miocene biogeography of the entire Atlantic Ocean. These results have not been published earlier and are included here so that the Miocene assemblage of the Falkland Plateau can be effectively compared with the remainder of the Atlantic Ocean. Figures 4 to 11 show the time/latitudinal distributions of various nannoplankton assemblages during the Miocene.

Like the early Tertiary, Miocene assemblages show distinct latitudinal differentiations. In the earliest Miocene (NN1 Zone) the late Oligocene biogeographic patterns continue. Cyclococcolithus neogammation and Dictyococcites hesslandii continue to dominate the low to mid latitudes, but in the northern high latitudes these taxa are less prominent, Coccolithus pelagicus being the most dominant taxon. This essentially Oligocene pattern changes in the NN2 Zone when a discoaster assemblage achieves dominance in the low to mid latitudes and Cyclococcolithus neogammation continues to be abundant only in the low latitudes. During the remainder of the early Miocene (NN2 to NN4 zones), these patterns remain relatively stable, and there is little variation in the makeup of the latitudinal assemblages with the exception of a general reduction in the abundance of Dictyococcites hesslandii. The northern high latitudes contain a stable Coccolithus pelagicus assemblage.

During the early Miocene the Falkland Plateau area was dominated by the cosmopolitan taxon, Dictyococcites hesslandii, and the cool Coccolithus pelagicus. Cyclococcolithus neogammation occurs in less abundant numbers (see Table 1).

In the lower part of the middle Miocene (NN5 Zone) the patterns change again. A tropical assemblage dominated by two small coccolith taxa, Dictyococcites minutus (Haq) n. comb., and Cyclococcolithus aff. stradneri Jafar, appears in the low latitudes and spreads quickly to the mid latitudes. These taxa, with lesser amounts of Reticulofenestra pseudoumbilica and discoasters, remain dominant in the lower latitudes up to the NN8 Zone of the upper mid Miocene. The earlier discoaster dominated low-latitude assemblage is displaced towards the mid latitudes at this time (DSDP Site 10). Minor amounts of Dictyococcites minutus also start appearing in the northern high latitudes in the NN5 Zone and become dominant in the NN6 Zone, remaining dominant until the NN8 Zone.

At the Falkland Plateau (Site 329) a new assemblage dominated by Dictyococcites antarcticus Haq, appears in the middle Miocene. D. antarcticus seems restricted to southern high latitudes and true $D$. antarcticus has not been recorded from other areas. This assemblage is essentially the same recorded in the Miocene of the Bellingshausen Abyssal Plain during DSDP Leg 35 (see Haq, 1976).

In the upper middle Miocene the discoaster-dominated assemblage again returns to the low latitudes and Dictyococcites minutus and Cyclococcolithus aff. stradneri are sharply reduced in both the low and mid latitudes. Northern high latitudes are also once again dominated by Coccolithus pelagicus in the NN9-NN10 zones. This general pattern continues into the lower part of the late Miocene (lower NN11 Zone).

In the upper part of the late Miocene (upper NN11 and NN12 zones) and earliest Pliocene (NN13 Zone) a second expansion of Dictyococcites minutus and Cyclococcolithus aff. stradneri takes place in the low latitudes. Once again these tropical elements spread into the mid and high latitudes-the northern high latitudes are dominated by Dictyococcites minutus and Coccolithus pelagicus through the NN12/NN13 zones.

Throughout the middle and late Miocene the Falkland Plateau assemblages are essentially dominated by Dictyococcites antarcticus, with some variations in the late Miocene when Coccolithus pelagicus becomes important in one interval and Reticulofenestra pseudoumbilica becomes prominent in another interval (see Table 1).

\section{Miocene Paleoclimatology of the Atlantic Ocean}

The Miocene migrations of nannoplankton assemblages through latitudes can be interpreted as responses of the latitudinally restricted floras to major climatic changes. The Miocene climatic history can be summarized as follows: (1) The relatively warm late Oligocene climatic trend continues into the earliest Miocene (23 to 21.5 m.y.B.P.). This is indicated by the presence of late Oligocene Dictyococcites hesslandii and Cyclococcolithus neogammation assemblages in the low to high latitudes. Elements of these assemblages are also common on the Falkland Plateau during this time; (2) A cooling event between 19 and 17 m.y.B.P. is indicated by the decrease in the Dictyococcites hesslandii and Cyclococcolithus neogammation assemblages in low latitudes and invasion of the high latitude Coccolithus pelagicus assemblage into mid latitudes; (3) A major warming trend between 15 and 13 m.y.B.P. is evidenced by the emergence and spread of the tropical Dictyococcites minutus and Cyclococcolithus aff. stradneri assemblages in all latitudes. An austral assemblage 


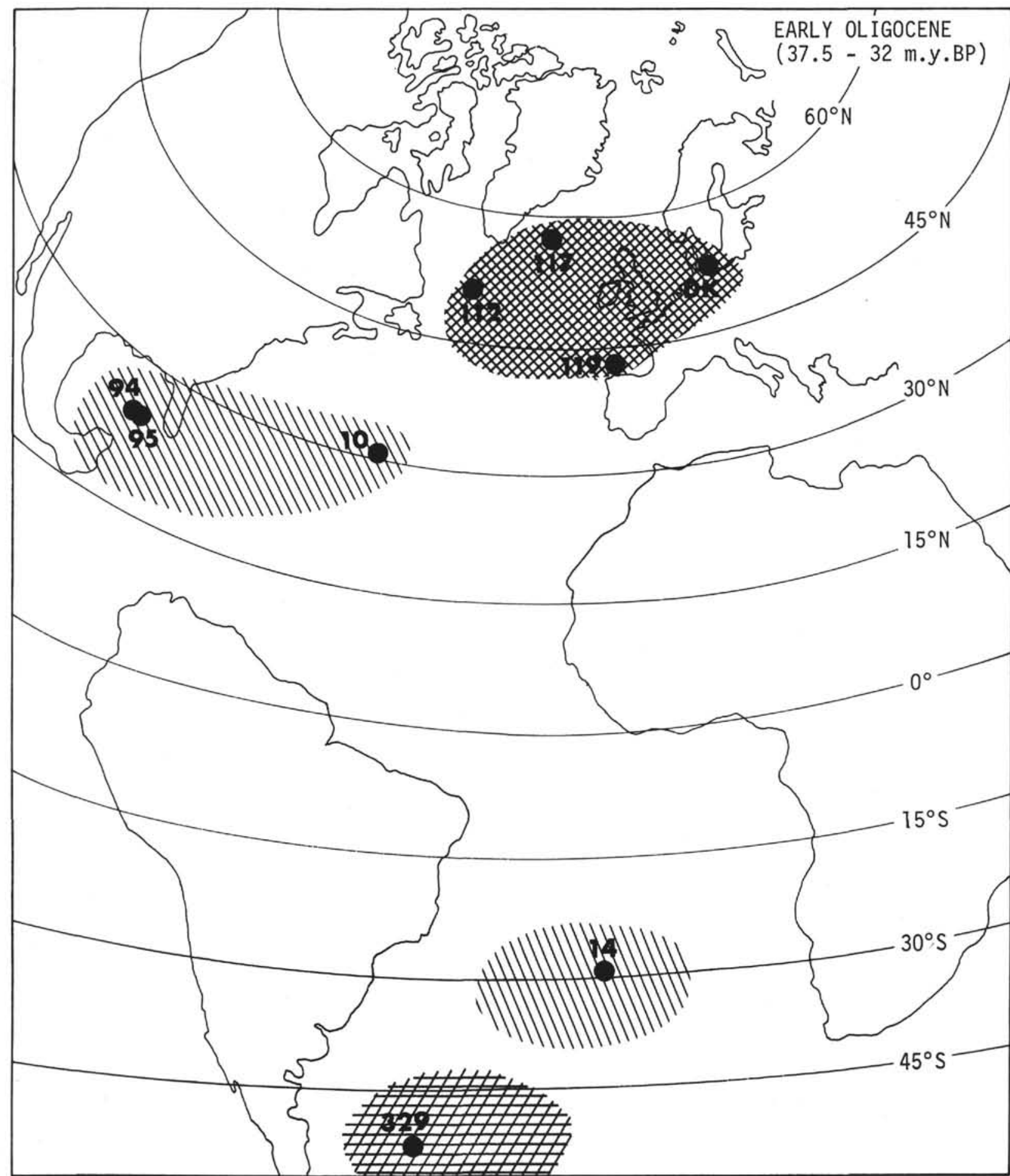

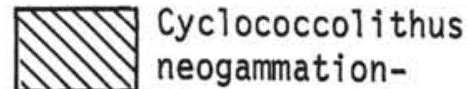
neogammationDictyococcites hesslandii Assemblage
ReticulofenestridChiasmolith Assemblage

Figure 3. Early Oligocene calcareous nannoplankton biogeography. 
1 DSDP 18-3, 2-144

2 DSDP 22-1, 6-81

3 DSDP 27-3, 2-124

5 DSDP 116-19, 1-91

DSDP $149-26,1-64$

8 DSDP 151-7, 1-5

9 DSDP $149-23,3-102$

10 DSDP $15-9,6-120$

12 DSP $116-14$, CC

13 DSDP $151-4,2-125$

14 DSDP 14-1A, 3-65

15 DSDP $151-4,1-120$
16 DSDP $116-13$, CC

17 DSDP 14-1A, 3-52

18 DSDP $18-2,2-144$

20 DSDP $119-7,3-125$

21 DSDP 149-21, 1-91

22 DSDP $329-27,1-120$

$\begin{array}{lll}23 & \text { DSDP } 94-9,6-144 \\ 24 & \text { DSDP } 15-7,1-27\end{array}$

25 DSDP $149-20,5-125$

26 DSDP $151-4,1-68$

28 DSDP $94-9,2-74$

29 DSDP 15-6, 6-144

30 DSDP $149-17,5-14$

32 DSDP $141-5,1-5$

33 DSDP 119-5, 2-122

34 DSDP 149-15, 4-10

35 DSDP $116-9,1-29$

36 OSDP $10-2,3-145$

38 DSDP $151-3,6-145$

39 DSDP $149-15,3-124$

40 DSDP $30-12,1-7.5$

41 DSDP 116-8, 3-139

42 DSDP $10-2,3-10$

43 DSDP 116-6, 1-29

45 DSDP $149-14,1-110$

46 DSDP 142-8, 1-27

47 DSDP $97-4,2-8$

48 DSDP $97-3,3-124$

49 DSDP $329-19,4-100$

51 DSDP $15-5,6-144$

52 DSDP 329-17, 2-100

53 DSDP 329-15, 4-102

54 DSDP 94-8, 5-124

55 DSDP $98-4,6-139$

57 DSDP $329-9,1-100$

8 DSDP 329-3, 6-98

60 DSDP $142-7,6-120$

61 DSDP 94-7, 1-113

62 DSDP $116-5,5-119$

63 DSDP 98-3, 3-49

65 DSDP 151-2, $3-140$

65 DSP 151-2, $3-140$

7 DSDP 118-5, 2-44

68 DSDP $116-3,6-117$
69 DSDP $114-6,6-134$

\begin{tabular}{|c|c|c|}
\hline$-28^{\circ} \mathrm{S}$ & 21.5 & 20.5 \\
\hline$-30^{\circ} \mathrm{S}$ & 22.5 & \\
\hline $16^{\circ} \mathrm{N}$ & 24.0 & 22.5 \\
\hline $24^{\circ} \mathrm{N}$ & 22.5 & 21.5 \\
\hline $58^{\circ} \mathrm{N}$ & 24.0 & 22.5 \\
\hline $45^{\circ} \mathrm{N}$ & 24.0 & 22.5 \\
\hline $15^{\circ} \mathrm{N}$ & 24.0 & 20.5 \\
\hline $15^{\circ} \mathrm{N}$ & 24.0 & 20.5 \\
\hline $15^{\circ} \mathrm{N}$ & 21.0 & 19.5 \\
\hline$-31^{\circ} \mathrm{S}$ & 20.5 & 19.5 \\
\hline $4^{\circ} 1$ & 20.5 & 19.5 \\
\hline $58^{\circ} \mathrm{N}$ & 20.5 & 19.5 \\
\hline $15^{\circ} \mathrm{N}$ & 20.5 & 19.5 \\
\hline$-28^{\circ} \mathrm{S}$ & 20.5 & 19.5 \\
\hline $15^{\circ} \mathrm{N}$ & 20.0 & 17.5 \\
\hline $58^{\circ} \mathrm{N}$ & 19.5 & 17.5 \\
\hline$-28^{\circ} \mathrm{S}$ & 19.5 & 17.5 \\
\hline$-28^{\circ} \mathrm{S}$ & 19.5 & 17.5 \\
\hline $45^{\circ} \mathrm{N}$ & 19.5 & 17.5 \\
\hline $34^{\circ} \mathrm{N}$ & 19.5 & 17.5 \\
\hline $15^{\circ} \mathrm{N}$ & 19.5 & 17.5 \\
\hline$-51^{\circ} \mathrm{S}$ & 22.5 & 21.0 \\
\hline $25^{\circ} \mathrm{N}$ & 17.5 & 16.5 \\
\hline$-31^{\circ} \mathrm{S}$ & 17.5 & 16.5 \\
\hline $15^{\circ} \mathrm{N}$ & 17.5 & 16.5 \\
\hline $15^{\circ} \mathrm{N}$ & 17.5 & 16.5 \\
\hline $58^{\circ} \mathrm{N}$ & 17.5 & 15.0 \\
\hline $25^{\circ} \mathrm{N}$ & 16.5 & 15.5 \\
\hline$-31^{\circ} \mathrm{S}$ & 16.5 & 15.0 \\
\hline $15^{\circ} \mathrm{N}$ & 16.5 & 15.0 \\
\hline & 16.5 & 15.0 \\
\hline$-51^{\circ}$ & 16.0 & 14.0 \\
\hline $45^{\circ} \mathrm{N}$ & 15.0 & 14.0 \\
\hline $15^{\circ} \mathrm{N}$ & 15.0 & 13.5 \\
\hline $58^{\circ} \mathrm{N}$ & 15.0 & 13.5 \\
\hline $33^{\circ} \mathrm{N}$ & 14.5 & 13.5 \\
\hline $15^{\circ} \mathrm{N}$ & 15.0 & 14.0 \\
\hline $15^{\circ} \mathrm{N}$ & 14.5 & 13.5 \\
\hline $15^{\circ} \mathrm{N}$ & 14.0 & 13.0 \\
\hline $13^{\circ} \mathrm{N}$ & 14.0 & 13.0 \\
\hline $58^{\circ} \mathrm{N}$ & 14.0 & 11.5 \\
\hline $33^{\circ} \mathrm{N}$ & 14.0 & 12.8 \\
\hline $58^{\circ} \mathrm{N}$ & 13.0 & 9.5 \\
\hline $19^{\circ} \mathrm{N}$ & 12.8 & 11.3 \\
\hline $15^{\circ} \mathrm{N}$ & 12.8 & 11.3 \\
\hline $3^{\circ} \mathrm{N}$ & 12.5 & 9.5 \\
\hline $26^{\circ} \mathrm{N}$ & 12.8 & 10.0 \\
\hline $26^{\circ} \mathrm{N}$ & 12.0 & 9.5 \\
\hline$-51^{\circ} \mathrm{S}$ & 12.0 & 10.0 \\
\hline $35^{\circ} \mathrm{N}$ & 11.0 & 9.5 \\
\hline$-31^{\circ} \mathrm{S}$ & 11.0 & 9.5 \\
\hline$-51^{\circ} \mathrm{s}$ & 11.0 & 9.0 \\
\hline$-51^{\circ}$ & 10.5 & 8.5 \\
\hline $25^{\circ} \mathrm{N}$ & 9.5 & 7.5 \\
\hline 25 & 9.5 & 7.5 \\
\hline-51 & 10.0 & 8.0 \\
\hline-51 & 9.0 & 7.0 \\
\hline$-51^{\circ} \mathrm{S}$ & 8.0 & 6.0 \\
\hline $21^{\circ} \mathrm{N}$ & 8.0 & 5.5 \\
\hline 30 & 7.5 & 5.5 \\
\hline $25^{\circ}$ & 7.5 & 5.5 \\
\hline $58^{\circ}$ & 7.5 & 5.5 \\
\hline $25^{\circ}$ & 7.5 & 5.5 \\
\hline $24^{\circ}$ & 7.5 & 5.5 \\
\hline $15^{\circ}$ & 5.5 & 5.0 \\
\hline $19^{\circ}$ & 5.5 & 5.0 \\
\hline & 5 & \\
\hline & & \\
\hline & 5.5 & 4. \\
\hline
\end{tabular}

${ }^{6.00}\left[\begin{array}{c}8.00 \\ 100\end{array}-\left[\begin{array}{l}58 \\ 57 \\ f_{56} \\ 53 \\ 52 \\ 49\end{array}\right.\right.$

$\Gamma^{80}$

I65 I I

$12.00-1$

51

高 14.00

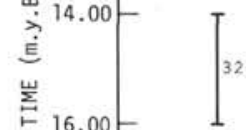

$20.00-$
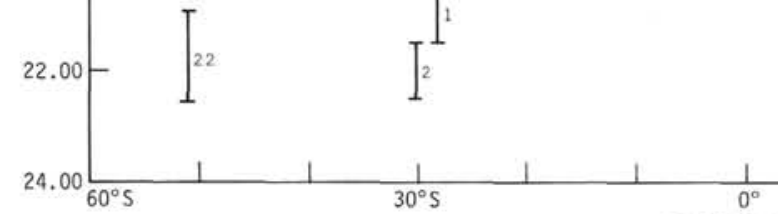

$\Gamma^{46}$

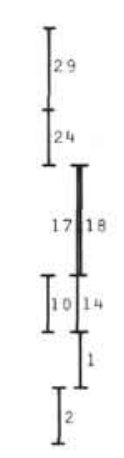

Figure 4. Time and paleolatitudinal distribution of Miocene samples. Numbers refer to sample list on the left. Length of line segment beside each number reflects uncertainty of sample's estimated age. Some samples are used in illustrating the distribution patterns of assemblages in Figures 5-11. 


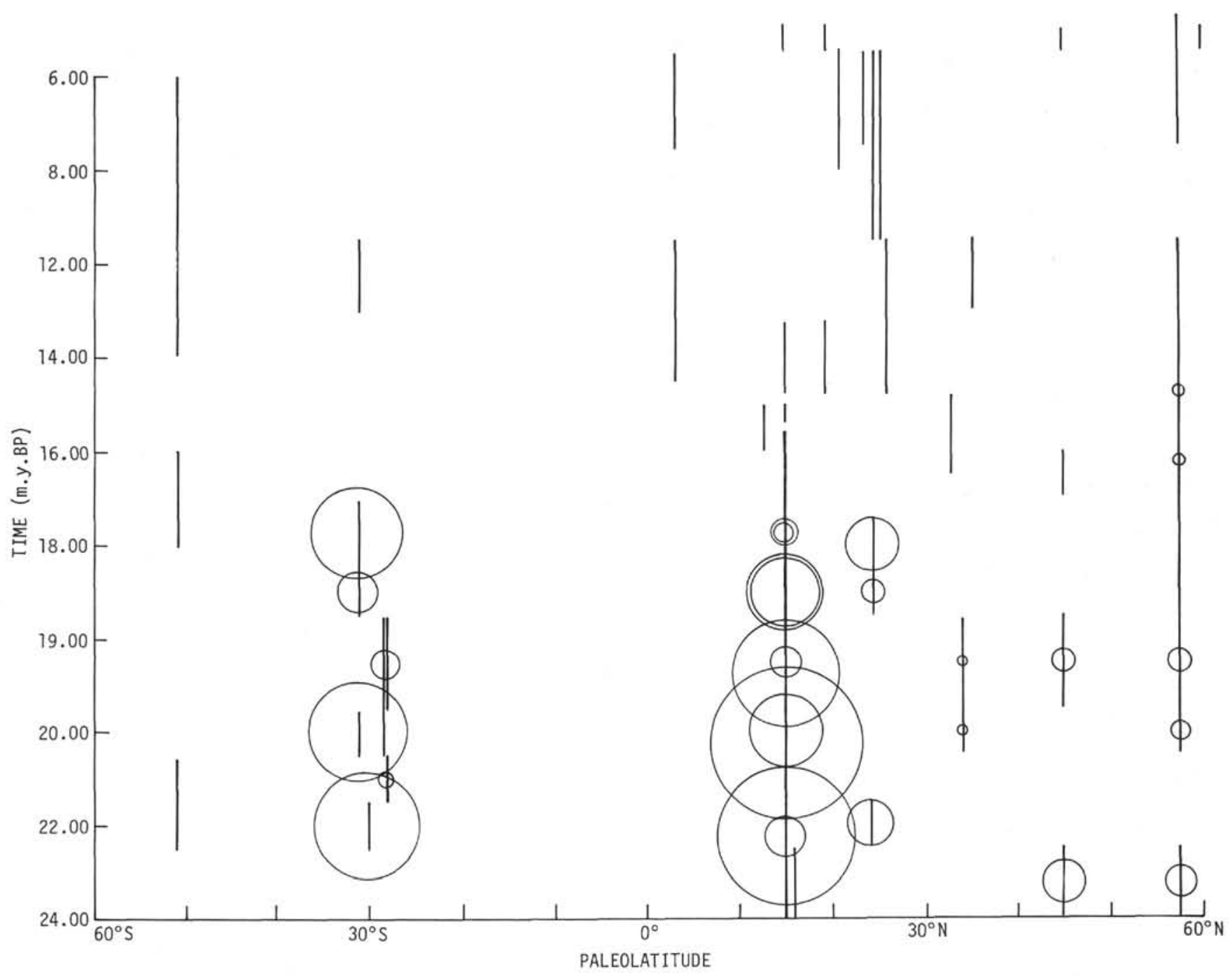

Figure 5. Time and paleolatitudinal distributions of Miocene assemblages identified by Q-mode Varimax Factor Analysis. Sizes of circles are proportional to abundance of the assemblage in each sample. Cyclococcolithus neogammation assemblage.

dominated by Dictyococcites antarcticus appears in the Southern Ocean at this time and maintains itself throughout the remainder of the Miocene; (4) A second cooling event between 13 and 9 m.y.B.P. is shown by the reduction of the Dictyococcites minutus and Cyclococcolithus aff. stradneri assemblages; (5) Another warming event in the late Miocene ( 8 to 5 m.y.B.P.) is indicated by the re-establishment of the Dictyococcites minutus and Cyclococcolithus aff. stradneri assemblages in the low to high latitudes.

\section{Discussion}

The late Paleocene biogeographic map of the paleoAtlantic basin (Figure 2) shows the latitudinal spread of the relatively warm Toweius craticulus-Coccolithus pelagicus assemblage into the mid and high latitudes. The North Atlantic site in Hatton-Rockall Basin (117), however, maintains a typically boreal assemblage dominated by Prinsius martinii which develops in the early Paleocene and dominates the northern high lati- tudes from 63 to about 54 m.y.B.P. Haq and Lohmann (1976) have shown evidence that after a cooler middle Paleocene, when high latitude nannoflora invaded the low latitudes of the Atlantic, the cooler ( $P$. martinii) assemblage withdrew back to higher latitudes and in the late Paleocene-early Eocene, a low latitude nannoflora spread into northern high latitudes eventually replacing the boreal assemblage between 52 and 50 m.y.B.P. in response to a sharp climatic warming trend that culminated in the warmest period of the early Cenozoic during the early Eocene. The biogeographic map presented here (Figure 2) is a "snap-shot" of the Atlantic Ocean after the beginning of this warming trend, but before the total spread of low latitude assemblages all the way to the highest latitudes.

The dominant presence of the Toweius craticulusCoccolithus pelagicus assemblage at Site 329 indicates that the late Paleocene spread of this assemblage is symmetrical and confirms a warming Atlantic Ocean relative to the mid-Paleocene. Presence of abundant 


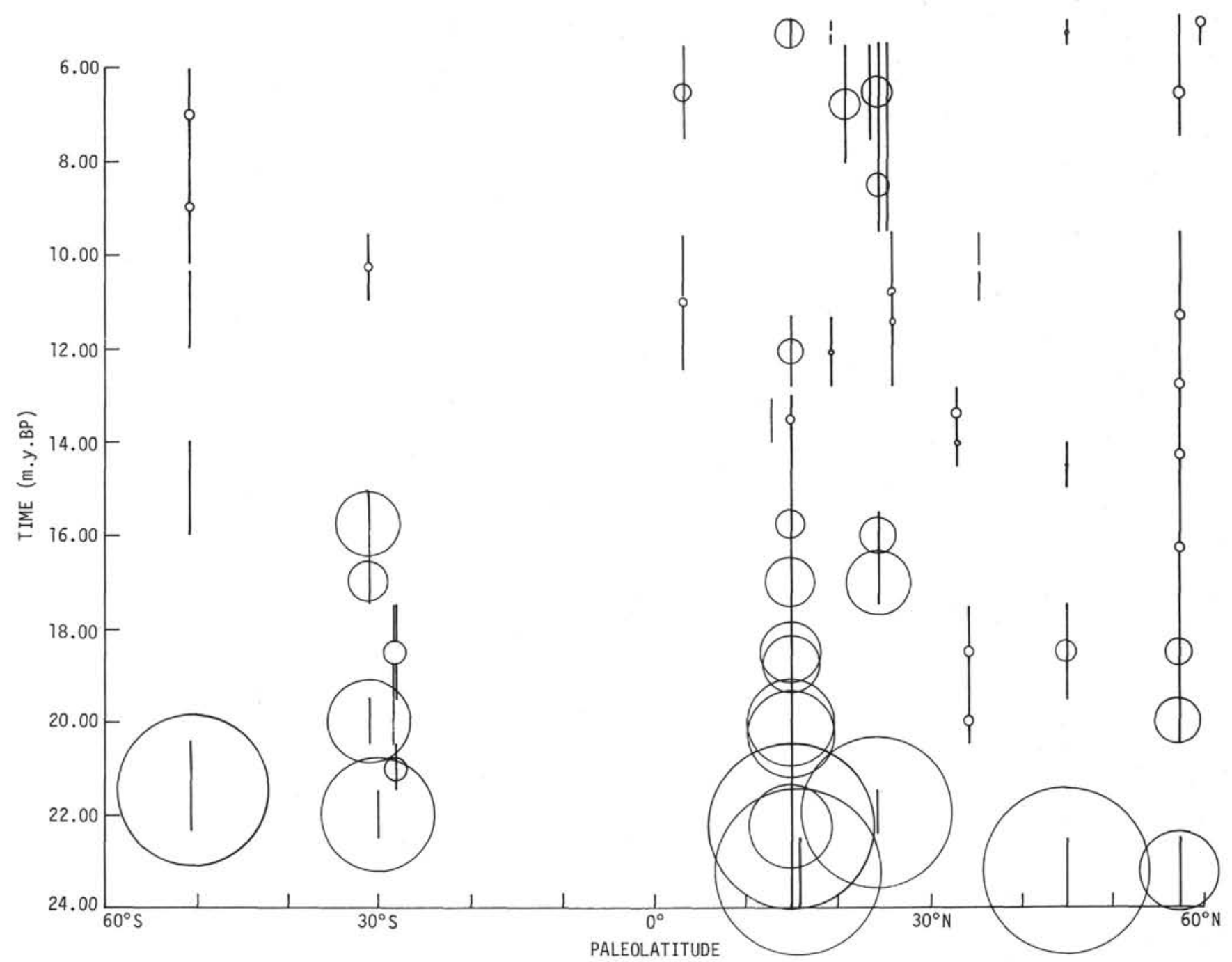

Figure 6. Time and paleolatitudinal distributions of Miocene assemblages identified by Q-mode Varimax Factor Analysis. Sizes of circles are proportional to abundance of the assemblage in each sample. Dictyococcites hesslandii assemblage.

chiasmoliths at this site may indicate continued influences of cooler nannofloral elements of the southern high latitudes. Chiasmoliths are generally considered to prefer cooler waters and a Discoaster/Chiasmolithus $(\mathrm{D} / \mathrm{C})$ ratio is sometimes used to differentiate warm/cool climatic fluctuations (Bukry, 1973). In Table 3 we present the $\mathrm{D} / \mathrm{C}$ ratios in the Upper Paleocene-lower Eocene samples from Site 329. It is clear that the relative chiasmolith content is always high but the $\mathrm{D} / \mathrm{C}$ ratio varies considerably (1:299 to $1: 1)$. If there were a simple relationship between $\mathrm{D} / \mathrm{C}$ ratio and climatic fluctuations, the present data would indicate a change from very cold to relatively warm climates within the lower part of the Discoaster multiradiatus Zone on the Falkland Plateau. Other paleobiogeographic data, however, indicate warming climates through the late Paleocene-early Eocene interval throughout the Atlantic basin. Although they represent generally cooler temperatures, the paleoenvironmental preferences of chiasmoliths have not yet been accurately delineated, and a simplistic relationshïp between $\mathrm{D} / \mathrm{C}$ ratios and climatic fluctuation may not exist. Moreover, their dearth in the northern higher latitudes, both in the late Paleocene and early Oligocene, in comparison to the southern high latitudes where they are abundant in both of these intervals, makes their unquestioned use as paleoenvironmental indicators suspect.

The early Oligocene biogeographic map of the paleoAtlantic (Figure 3 ) shows a latitudinally more differentiated nannoflora than the late Paleocene. The mid latitudes are dominated by the intermediate Cyclococcolithus neogammation-Dictyococcites hesslandii assemblage. This assemblage also forms an important part of the northern high latitudes, but here the reticulofenestrid and Coccolithus pelagicus assemblages are equally abundant. The southern high latitude site (329) is dominated by reticulofenestrids and chiasmoliths. These differences, particularly the lack of Cyclococcolithus neogammation-Dictyococcites hesslandii at Site 329, indicate a cooler southern Atlantic relative to the northern ocean during the early Oligocene. This dis- 
B. U. HAQ, G. P. LOHMANN, S. W. WISE, JR.

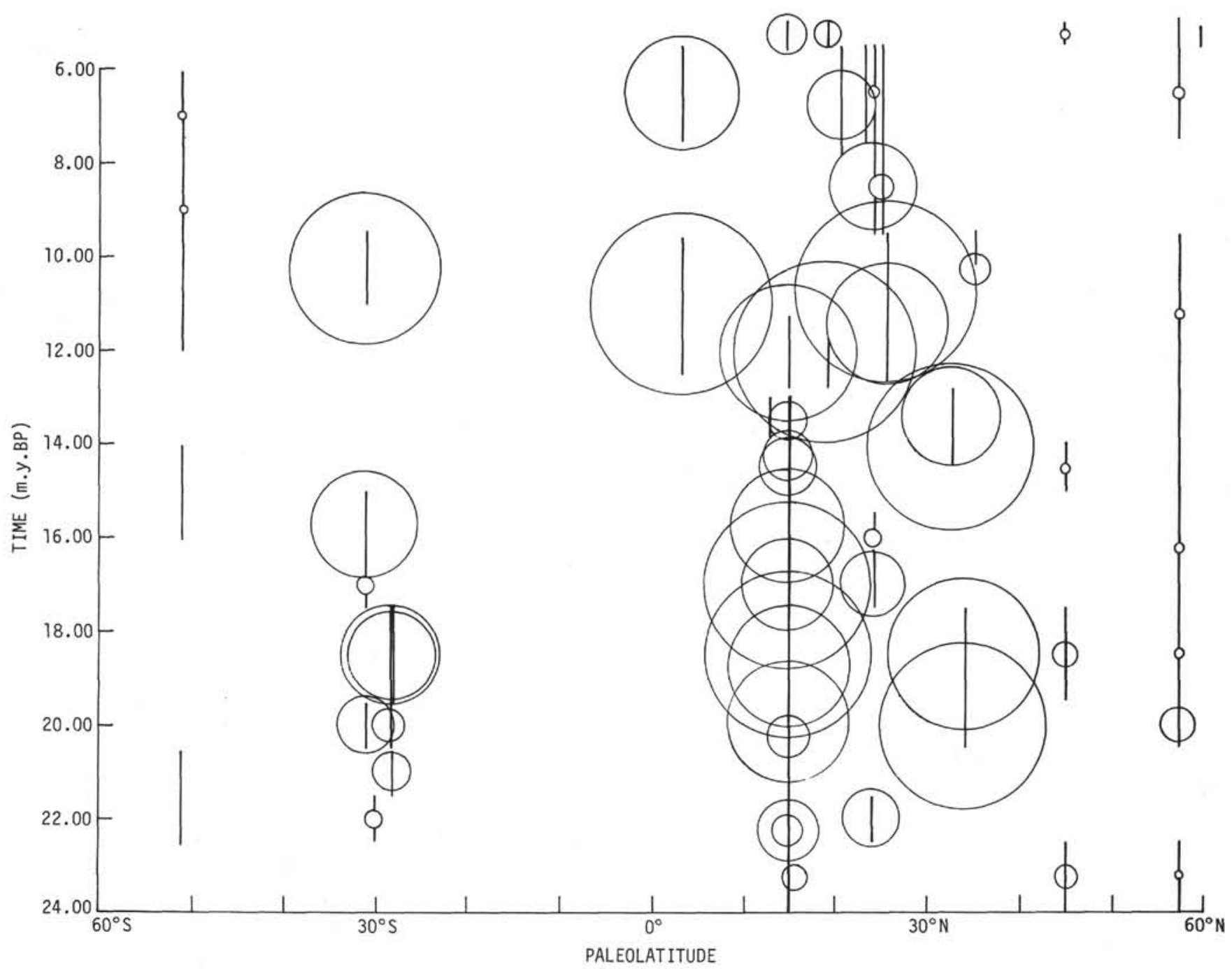

Figure 7. Time and paleolatitudinal distributions of Miocene assemblages identified by Q-mode Varimax Factor Analysis. Sizes of circles are proportional to abundance of the assemblage in each sample. Discoaster assemblage. 


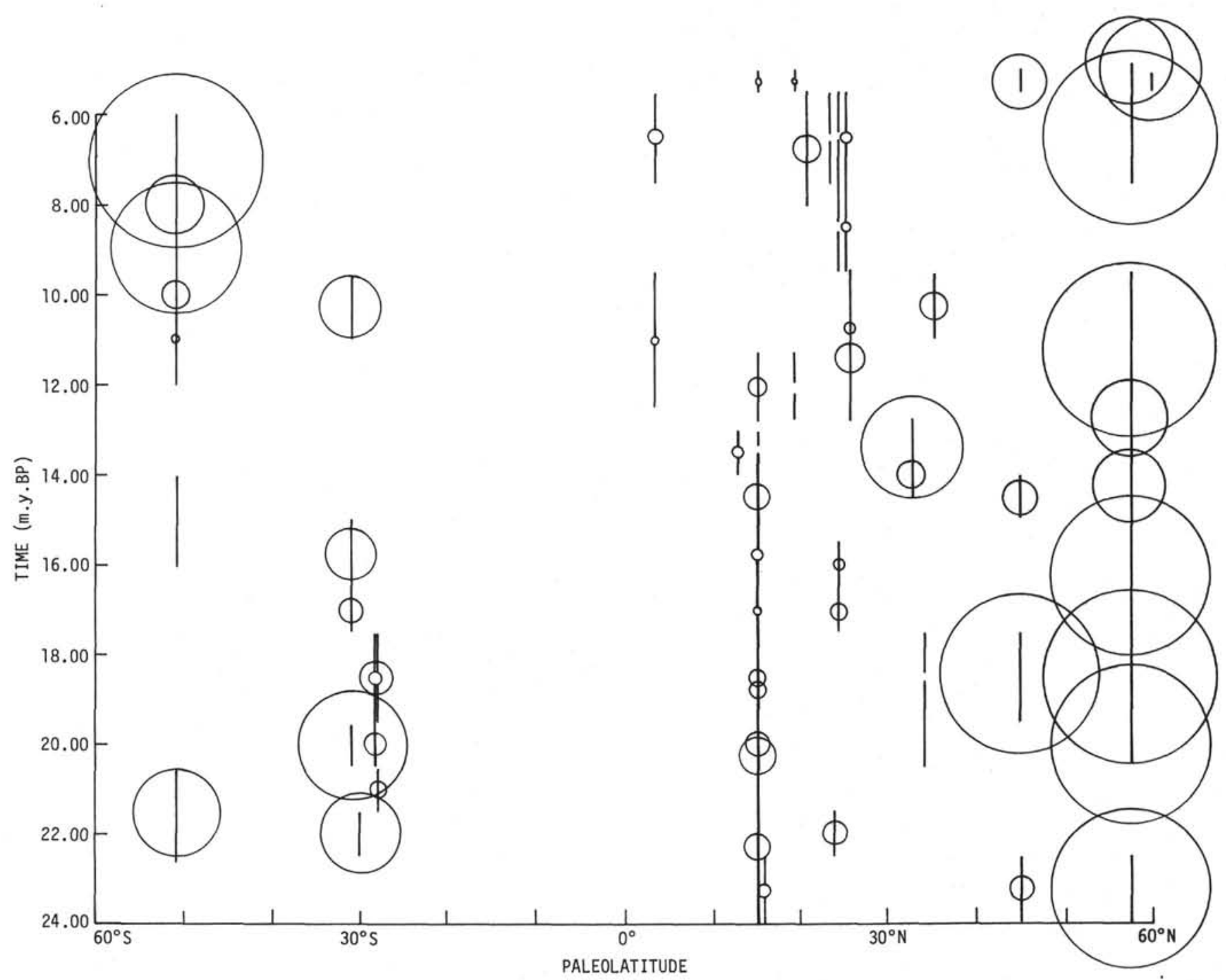

Figure 8. Time and paleolatitudinal distributions of Miocene assemblages identified by Q-mode Varimax Factor Analysis. Sizes of circles are proportional to abundance of the assemblage in each sample. Coccolithus pelagicus (s. ampl.) assemblage. 
B. U. HAQ, G. P. LOHMANN, S. W. WISE, JR.

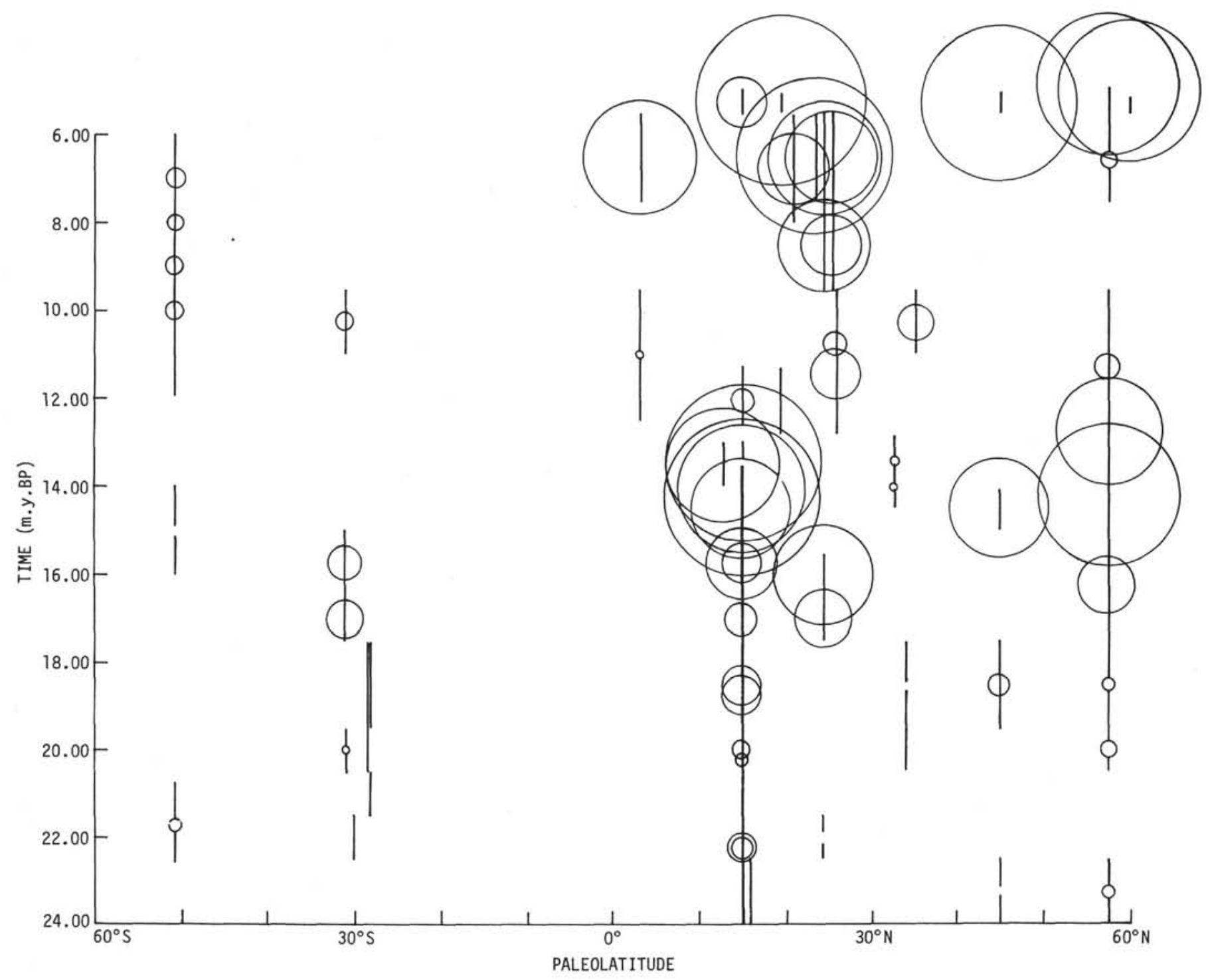

Figure 9. Time and paleolatitudinal distributions of Miocene assemblages identified by Q-mode Varimax Factor Analysis. Sizes of circles are proportional to abundance of the assemblage in each sample. Dictyococcites minutus assemblage. 


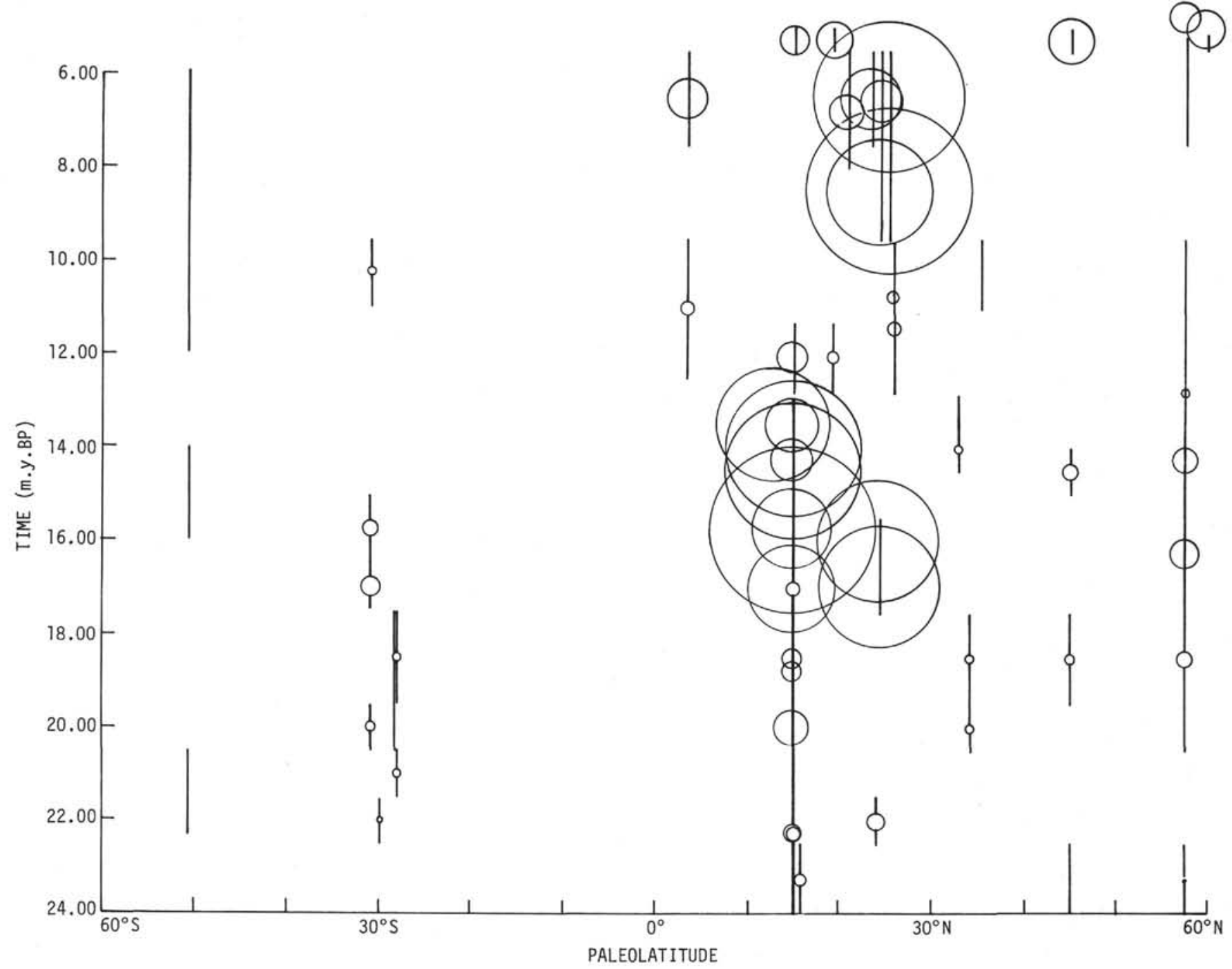

Figure 10. Time and paleolatitudinal distributions of Miocene assemblages identified by Q-mode Varimax Factor Analysis. Sizes of circles are proportional to abundance of the assemblage in each sample. Cyclococcolithus aff. stradneri assemblage. 
B. U. HAQ, G. P. LOHMANN, S. W. WISE, JR.

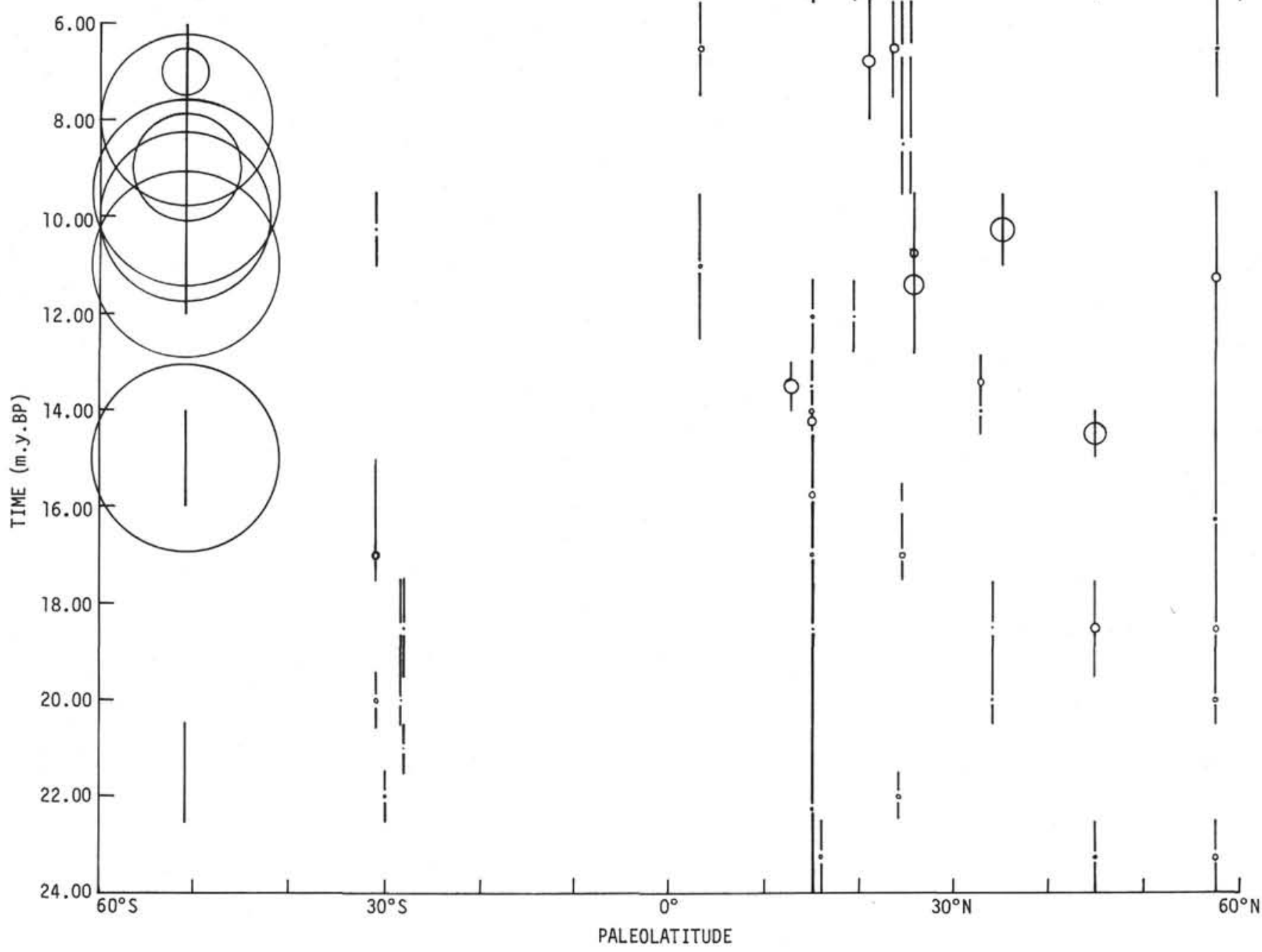

Figure 11. Time and paleolatitudinal distributions of Miocene assemblages identified by Q-mode Varimax Factor Analysis. Sizes of circles are proportional to abundance of the assemblage in each sample. Dictyococcites antarcticus assemblage. 
TABLE 3

Discoaster: Chiasmolithus Ratios, Site 329

\begin{tabular}{lcl}
\hline $\begin{array}{c}\text { Sample } \\
\text { (Interval in cm) }\end{array}$ & $\begin{array}{c}\text { (Discoaster: } \\
\text { Chiasmolithus) }\end{array}$ & Ratio \\
\hline $32-1,86-88$ & $26: 274$ & $1: 11$ \\
$32-1,127-129$ & $24: 276$ & $1: 11$ \\
$32-1,143-144$ & $12: 288$ & $1: 24$ \\
$32-4,5-7$ & $59: 241$ & $1: 4$ \\
$32-4,33-35$ & $42: 258$ & $1: 6$ \\
$32-4,67-69$ & $23: 277$ & $1: 12$ \\
$32-4,107-109$ & $50-250$ & $1: 5$ \\
$32-4,127-129$ & $78: 222$ & $1: 3$ \\
$33-1,94-95$ & $48: 252$ & $1: 5$ \\
$33-1,125$ & $25: 275$ & $1: 11$ \\
$33-1,139-141$ & $62: 238$ & $1: 4$ \\
$33-2,9-11$ & $146: 154$ & $1: 1$ \\
$33-2,70-72$ & $30: 270$ & $1: 9$ \\
$33-2,125-126$ & $12: 288$ & $1: 24$ \\
$145-146$ & $11: 289$ & $1: 26$ \\
$33-3,10-12$ & $11: 289$ & $1: 26$ \\
$33-3,70-72$ & $26: 274$ & $1: 11$ \\
$33-3,118-120$ & $64: 236$ & $1: 4$ \\
$33-3,143-145$ & $92: 208$ & $1: 2$ \\
$33-4,77-80$ & $4: 296$ & $1: 74$ \\
$33-4,100-102$ & $1: 299$ & $1: 299$ \\
$33-4,134-135$ & $3: 297$ & $1: 99$ \\
\hline
\end{tabular}

crepancy could be explained by invoking a paleo-Gulf Stream and its warming influence; Sites 112 and 117 would lie directly in its path. Alternatively, the generally cooler southern high latitudes during this period may be due to the same reason that eventually caused the global climatic deterioration in the early Oligocene, i.e., the onset of Antarctic glaciation near the Eocene/Oligocene boundary and increased bottom water production and circulation (Kennett et al., 1975). This general trend of cooler southern high latitudes extends into the Miocene as evidenced by the dominance of the cool Dictyococcites antarcticus assemblage at Site 329.

\section{TAXONOMIC NOTES}

Cyclococcolithus aff. stradneri Jafar, Verh. Kon. Ned. Akad. Wet. Afd. Natuurk., v. 28 , no. 1 , p. 75,76 , pl. 9 , fig. $22-25$.
Remarks: The small circular placoliths observed in the tropical/subtropical Atlantic DSDP sites have dimensions similar to C. stradneri. However, the present species does not show a prominent central pore. The placoliths have relatively large thickness compared to the diameter of the shields, and the two shields are almost always separated from each other, leaving a knob on one shield and a "pseudo-pore" on the other.

Dictyococcites minutus (Haq) n. comb. Basionym: Prinsius minutus Haq, Stockholm Contrib. Geol., v. 25 , no. 2, p. 78 , pl. 7, fig. 4 , 5.

\section{ACKNOWLEDGMENTS}

This paper was reviewed by W.A. Berggren and R.C. Tjalsma. Research was supported by Grant GA 21983 of the Submarine Geology and Geophysics program, Oceanography Section of the National Science Foundation. This is Woods Hole Oceanographic Institution Contribution No. 3748.

\section{REFERENCES}

Bukry, D., 1973. Coccolith and silicoflagellate stratigraphy, Tasman Sea and Southwestern Pacific Ocean, Deep Sea Drilling Project Leg 21. In Burns, R.E., Andrews, J.E., et al., Initial Reports of the Deep Sea Drilling Project, Volume 21: Washington (U.S. Government Printing Office), p. 885-893.

Edwards, A.R. and Perch-Nielsen, K., 1975. Calcareous nannofossils from the southern SW Pacific, DSDP Leg 29. In Kennett, J.P., Houtz, R.E., et al., Initial Reports of the Deep Sea Drilling Project, Volume 29: Washington (U.S. Government Printing Office), p. 469-539.

Haq, B.U., 1976. Coccoliths in cores from Bellingshausen Abyssal Plain and Antarctic continental Rise (DSDP Leg 35). In Craddock, C., Hollister, C.D., et al., Initial Reports of the Deep Sea Drilling Project, Volume 35: Washington (U.S. Government Printing Office), p. 557.

Haq, B.U. and Lohmann, G.P., 1976. Early Cenozoic calcareous nannoplankton biogeography of the Atlantic Ocean: Marine Micropaleo., v. 1, no. 2.

Kennett, J.P., Houtz, R.E., et al., 1975. Cenozoic paleooceanography in the Southwest Pacific Ocean, Antarctic glaciation, and the development of the Circum-Antarctic Current. In Kennett, J.P., Houtz, R.E., et al., Initial Reports of the Deep Sea Drilling Project, Volume 29: Washington (U.S. Government Printing Office), p. 11551169. 